\title{
Sitotoksisitas pemutih gigi berdasarkan konsentrasi bahan
}

\author{
*Mardiana A. Adam, **Asti Meizarini \\ *Bagian Periodontologi, Fakultas Kedokteran Gigi Universitas Hasanuddin, Makassar \\ **Departemen Material Kedokteran Gigi, Fakultas Kedokteran Gigi Universitas Airlangga, Surabaya \\ Indonesia
}

\begin{abstract}
The aim of this study was to evaluate the cytotoxicity of several tooth whitening material, carbamide peroxide 10\%, 15\%, 20\% and hydrogen peroxide 38\% toward BHK-21 cell using MTT assay. Each well of microplates which used for the test were aliquotted BHK21 cell suspension, after that the test solution were added to eight well each group, respectively. The result showed that percentages of the living cell at $10 \%$ carbamide peroxide group $=86,73 \% ; 15 \%=81,22 \% ; 20 \%=81,82 \% ; 38 \%$ hidrogen peroksida $=$ 64,08\%, respectively. Anova test and LSD showed no significant difference between 10\%, $15 \%, 20 \%$ groups, but there are significant toward 38\% group and control. The 38\% hydrogen peroxide group is expectable to be more cytotoxic than those containing $10 \%$ carbamide peroxide, which is equivalent to $3.6 \%$ hidrogen peroxide. Conclusion. The 10\%, 15\%, $20 \%$ carbamide peroxide and 38\% hydrogen peroxide tooth whitening agents were not cytotoxic toward BHK-21 cell line using MTT assay within $C D_{50}$.
\end{abstract}

Key words: cytotoxicity, tooth whitening material, MTT assay

\begin{abstract}
ABSTRAK
Tujuan penelitian ini untuk mengetahui sitotoksisitas bahan pemutih gigi karbamid peroksida $10 \%, 15 \%, 20 \%$ dan hidrogen peroksida 38\% terhadap sel BHK-21 menggunakan esei $M T T$. Setiap sumuran pada microplate yang dipakai untuk pengujian diisi sel $B H K-21$, kemudian ditambahkan bahan uji pemutih gigi sesuai kelompok. Didapatkan persentase sel hidup kelompok karbamid peroksida $10 \%=86,73 \% ; 15 \%=$ $81,22 \% ; 20 \%=81,82 \%$; hidrogen peroksida $38 \%=64,08 \%$. Uji Anova dan $L S D$ mendapatkan tidak ada perbedaan bermakna diantara kelompok 10\%, 15\%, 20\%, tetapi berbeda bermakna dengan kelompok $38 \%$ dan kontrol. Kelompok hidrogen peroksida $38 \%$ lebih toksik dari pada kelompok karbamid peroksida 10\% yang setara dengan 3,6\% hidrogen peroksida. Dapat disimpulkan bahwa bahan pemutih gigi karbamid peroksida $10 \%, 15 \%, 20 \%$ dan hidrogen peroksida 38\% tidak sitotoksik terhadap sel BHK-21 menggunakan esei $M T T$ dengan parameter $C D_{50}$.
\end{abstract}

Kata kunci: sitotoksisitas, bahan pemutih gigi, esei $M T T$

Koresponden: Mardiana A. Adam, Bagian Periodontologi Fakultas Kedokteran Gigi Universitas Hasanuddin, Jl. Kandea No 5 Makassar 90135, Indonesia.

\section{PENDAHULUAN}

Prosedur untuk pemutihan gigi ada berbagai macam cara. Pemutihan gigi dapat dikerjakan di klinik oleh dokter gigi secara langsung atau dilakukan di rumah dengan pantauan dokter gigi. Kandungan utama bahan pemutih gigi antara lain hidrogen peroksida, karbamid peroksida atau urea peroksida, atau sistim non hidrogen peroksida yang mengandung sodium klorida, oksigen dan natrium fluorida. Konsentrasi bahan pemutih gigi bermacam-macam tergantung kegunaan, di rumah atau di klinik. Bahan pemutih gigi karbamid 
peroksida yang sering digunakan di rumah konsentrasinya bervariasi antara 10, 15 dan $20 \%$. Sedangkan bahan pemutih gigi hidrogen peroksida untuk penggunaan di klinik biasanya menggunakan konsentrasi $35 \%$ atau lebih.

American Dental Association (ADA) ${ }^{1}$ melaporkan pemakaian bahan pemutih yang mengandung karbamid peroksida $10 \%$ aman dan efektif untuk penggunaan di rumah. Bahan dasar pemutih gigi karbamid peroksida $10 \%$ terdiri dari $3,6 \%$ hidrogen peroksida ${ }^{2}$ dan urea. Hidrogen peroksida menjadi bahan aktif pemutih gigi. Urea dalam karbamid peroksida berperan sebagai stabilisator untuk memperpanjang shelf life dan memperlambat pelepasan hidrogen peroksida. ${ }^{3}$ Kandungan lain dalam bahan pemutih peroksida adalah gliserin, karbopol, sodium hidroksida dan bahan perasa. Bahan pemutih gigi profesional yang diijinkan oleh ADA adalah hidrogen peroksida $35 \%$ dan penggunaannya memerlukan isolasi jaringan gingiva dengan rubber dam atau gel pelindung. Beberapa produk pemutih gigi mengandung bahan tambahan potasium nitrat dan ion fluorida untuk mengurangi sensitivitas gigi. $^{4-5}$

Tidak ada alat atau bahan kedokteran gigi yang sepenuhnya aman, termasuk bahan pemutih gigi. Pemilihan dan penggunaan alat atau bahan kedokteran gigi didasarkan asumsi bahwa keuntungan penggunaan jauh melebihi efek biologis yang merugikan. Uji sitotoksisitas adalah bagian dari evaluasi bahan kedokteran gigi dan diperlukan untuk prosedur skrining standar. Tujuan uji ini untuk mengetahui efek toksik suatu bahan secara langsung terhadap kultur sel. Cell lines telah banyak digunakan untuk menguji toksisitas berbagai bahan dan obat-obatan di bidang kedokteran gigi, antara lain sel baby hamster kidney-21 (BHK-21). Salah satu metode untuk menilai sitotoksisitas suatu bahan adalah esei tetrazolium MTT (3-(4,5-dimethylthiazol-2yl)-2,5-diphenyl tetrazolium bromide). ${ }^{6}$

Sejauh ini efek berbagai konsentrasi bahan pemutih gigi terhadap sitotoksisitas pada sel BHK-21 dengan menggunakan esei MTT belum diketahui. Untuk itu perlu diketahui apakah perbedaan konsentrasi bahan pemutih gigi karbamid peroksida 10\%, 15\%, 20\% dan hidrogen peroksida $38 \%$ berpengaruh terhadap sitotoksisitas sel BHK-21 dengan menggunakan esei MTT.

Tujuan penelitian ini untuk mengetahui sitotoksisitas bahan pemutih gigi karbamid peroksida $10 \%, 15 \%, 20 \%$ dan hidrogen peroksida $38 \%$ terhadap sel BHK-21 menggunakan esei MTT. Manfaatnya sebagai bahan pertimbangan dalam memilih bahan pemutih gigi yang tidak sitotoksik dan memberi informasi ilmiah kepada dokter gigi tentang variasi konsentrasi bahan pemutih gigi serta sitotoksisitasnya menggunakan esei $M T T$.

\section{METODE PENELITIAN DAN BAHAN}

Penelitian eksperimental laboratoris dengan rancangan penelitian post test only control group ini menggunakan bahan pemutih gigi karbamid peroksida Opalescence PF (Ultradent-USA) 10\%, $15 \%$, 20\%, dan hidrogen peroksida OpalescenceXtraBoost (Ultradent-USA) $38 \%$ sebagai subjek dan dilakukan di Laboratorium Pengendalian Mutu Peningkatan Produksi, Pusat Veterinaria Farma, Surabaya.

Pada penelitian ini digunakan kultur cell line BHK-21 pasase 60 (Pusvetma-Surabaya), media kultur Eagle's minimum essential medium (MEM) yang diperkaya dengan fetal bovine serum (FBS) $10 \%$, glutamin, asam amino, vitamin, KanamycinStreptomycin-Penicillin-Fungizone (PusvetmaSurabaya), pereaksi MTT (Sigma AldrichGermany), alkohol 70\%, phosphat buffer saline, dimethylsulfoxide (BDH-England), serta alat 
laminar flow (Oliphant-Australia), filter millipore Minisart 0,20 $\mu \mathrm{m}$ dan 0,45 $\mu \mathrm{m}$ (Sartorius), flask Nunc, microplate 96 well Nunc (NunclonDenmark), pipet mikro, pipet Pasteur, inkubator 5 $\% \mathrm{CO}_{2}$, shaker Vari Shaker (Dynatech-England), Elisa reader Opsysmr (Dynex-USA).

Berdasarkan jenis dan konsentrasinya sampel dibagi ke dalam 4 kelompok, yaitu Kelompok I menggunakan bahan uji gel karbamid peroksida konsentrasi 10\%, Kelompok II menggunakan bahan uji gel karbamid peroksida 15\%, Kelompok III menggunakan bahan uji gel karbamid peroksida 20\%, dan Kelompok IV menggunakan bahan uji gel hidrogen peroksida 38\%. Setiap kelompok menggunakan $10 \mathrm{mg}$ bahan uji yang dilarutkan dalam $50 \mathrm{ml} P B S$ sesuai dengan perbandingan bahan uji menurut $\mathrm{Li}$ et al, ${ }^{7}$ dengan besar sampel setiap kelompok 8 buah.

Disiapkan kultur sel fibroblas $B H K-21$ dengan kepadatan 2,4x104 sel/ml dalam media kultur Eagle's MEM, microplate dengan 96 well (sumuran) steril dan bekerja di dalam laminar flow. Sumuran pada microplate diisi sel fibroblas sebanyak 100 1. Bahan uji sampel yang telah dilarutkan dengan PBS, disaring menggunakan millipore $0,45 \mu \mathrm{m}$, kemudian ditambahkan ke dalam tiap sumuran sebanyak $20 \mu \mathrm{l}$, sesuai dengan kelompok sampel. Disiapkan pula kontrol sel dan kontrol media. Kontrol sel adalah tiap sumuran berisi sel fibroblas $B H K-21$ dalam media kultur Eagle's sebagai kontrol positif, dilakukan 8 kali pengulangan. Kontrol media adalah tiap sumuran yang berisi media kultur Eagle's saja sebagai kontrol negatif, dilakukan 8 kali pengulangan. Microplate dimasukkan ke dalam inkubator $5 \%$ $\mathrm{CO} 2$ suhu $37^{\circ} \mathrm{C}$ selama 20 jam. MTT $5 \mathrm{mg} / \mathrm{ml}$ dalam $P B S$, disiapkan dan disaring menggunakan millipore 0,20 $\mu \mathrm{m}$. Media di dalam sumuran dikeluarkan menggunakan syringe, sel melekat di dinding dalam sumuran. Pereaksi MTT ditambahkan sebanyak $10 \quad \mu$ l untuk setiap sumuran, ${ }^{7}$ kemudian diinkubasi kembali selama 4 jam. Total waktu inkubasi dalam inkubator $37{ }^{\circ} \mathrm{C}$ selama 24 jam. Setelah masa inkubasi selesai, MTT pada microplate dikeluarkan menggunakan syringe, kemudian ditambahkan larutan DMSO sebanyak $50 \mu$ tiap sumuran untuk menghentikan produk metabolik MTT. Microplate dikocok selama 5 menit. ${ }^{8}$ Nilai densitas optik formazan dideteksi dengan ELISA reader panjang gelombang $630 \mathrm{~nm}{ }^{9}$

Untuk mengetahui persentase jumlah sel hidup digunakan rumus: ${ }^{10}$

$\%$ sel hidup $=$ perlakuan + media $\times 100 \%$

$$
\text { sel }+ \text { media }
$$

Data yang diperoleh ditabulasi, lalu dilakukan analisis statistik menggunakan Anova satu arah dengan taraf kemaknaan 95\% dan dilanjutkan dengan uji least significant difference ( $L S D)$.

\section{HASIL}

Tabel 1 memperlihatkan rerata nilai densitas optik formazan pada kelompok IV yang menggunakan hidrogen peroksida $38 \%$ paling rendah dibandingkan kelompok yang menggunakan karbamid peroksida 10\%, 15\%,

Tabel 1. Nilai rerata densitas optik formazan bahan pemutih gigi, simpang baku dan persentase sel hidup.

\begin{tabular}{lcccccc}
\hline Bahan pemutih gigi & Kel I & Kel II & Kel III & Kel IV & Kontrol & $\begin{array}{c}\text { Kontrol } \\
\text { Media }\end{array}$ \\
\hline Jumlah sampel & 8 & 8 & 8 & 8 & 8 & 8 \\
Rerata densitas optik formazan & 0,151 & 0,138 & 0,139 & 0,099 & 0,181 & 0,048 \\
Simpang baku & 0,011 & 0,012 & 0,016 & 0,017 & 0,013 & 0,004 \\
\% Sel hidup & 86,73 & 81,22 & 81,82 & 64,08 & 100 & 0 \\
\hline
\end{tabular}

$\mathrm{KP}=$ karbamid peroksida, $\mathrm{HP}=$ hidrogen peroksida 
Tabel 2. Uji $L S D$ antar perlakuan dan kontrol

\begin{tabular}{lcccccc}
\hline \multicolumn{1}{c}{ Kelompok } & $\begin{array}{c}\text { Kel I } \\
\text { KP 10\% }\end{array}$ & $\begin{array}{c}\text { Kel II } \\
\text { KP 15\% }\end{array}$ & $\begin{array}{c}\text { Kel III } \\
\text { KP 20\% }\end{array}$ & $\begin{array}{c}\text { Kel IV } \\
\text { HP 38\% }\end{array}$ & $\begin{array}{c}\text { Kontrol } \\
\text { sel }\end{array}$ & $\begin{array}{c}\text { Kontrol } \\
\text { media }\end{array}$ \\
\hline Kel I - KP 10\% & - & TB & TB & B & B & B \\
Kel II - KP 15\% & & - & TB & B & B & B \\
Kel III - KP 20\% & & & - & B & B & B \\
Kel IV - HP 38\% & & & & - & B & B \\
Kontrol sel & & & & & - & B \\
Kontrol media & & & & & & - \\
\hline
\end{tabular}

$\mathrm{B}=$ Bermakna, $\mathrm{TB}=$ Tidak Bermakna

20\%. Kelompok III yang menggunakan karbamid peroksida $20 \%$ bila dibandingkan kelompok II (15\%), tidak tampak adanya penurunan nilai densitas optik formazan. Persentase sel hidup paling rendah, yaitu persentase densitas optik ensim mitokondrial dehidrogenase pada kultur sel BHK-21 kelompok yang menggunakan hidrogen peroksida 38\%. Persentase sel hidup paling tinggi pada kelompok I yang menggunakan karbamid peroksida $10 \%$.

Sebelum menganalisis hasil densitas optik formazan antar kelompok, terlebih dahulu dilakukan pengujian distribusi dan homogenitas sampel. Probabilitas normalitas pada uji Kolmogorov Smirnov didapatkan $\mathrm{p}=0,204$ menunjukkan semua kelompok mempunyai distribusi normal $(\mathrm{p}>0,05)$. Uji homogenitas varians dengan Levene didapatkan $\mathrm{p}=0,139$ menunjukkan semua kelompok homogen $(\mathrm{p}>0,05)$.

Setelah diketahui semua kelompok mempunyai distribusi normal dan homogen, maka untuk mengetahui adanya perbedaan nilai densitas optik formazan dilakukan uji parametrik Anova satu arah. Probabilitas yang didapatkan 0,000 $(\mathrm{p}<0,05)$, maka berarti ada perbedaan yang bermakna antar kelompok yang diuji. Untuk menentukan perbedaan kemaknaan antar kelompok perlakuan dan kelompok kontrol, dilakukan uji $L S D$ pada $\alpha=0,05$ dan kelompok perlakuan yang bermakna adalah yang mempunyai signifikansi kurang dari 0,05 ( $\mathrm{p}<0,05)$. Tabel 2 memperlihatkan tidak ada perbedaan bermakna antara kelompok I, II, III, tetapi ada perbedaan bermakna bila dibandingkan dengan kelompok IV dan kontrol.

\section{PEMBAHASAN}

Salah satu persyaratan bahan kedokteran gigi untuk dapat diaplikasikan pada rongga mulut adalah harus bersifat biokompatibel, antara lain tidak mengandung substansi toksik. ${ }^{11}$ Untuk membuktikannya, maka dilakukan uji sitotoksisitas secara in vitro pada kultur sel $B H K$ 21 menggunakan MTT assay. Penggunaan kultur sel $B H K-21$ yang berasal dari fibroblas ginjal bayi hamster, disebabkan karena sel fibroblas merupakan sel terpenting dan komponen terbesar dari pulpa, ligamen periodontal dan gingival. ${ }^{12}$ Hasil uji dengan menggunakan BHK-21 dapat dipakai sebagai dasar pengujian yang akurat. ${ }^{13}$ MTT assay didasarkan pada kemampuan sel hidup untuk mereduksi garam MTT. Prinsip assay ini adalah pemecahan cincin tetrazolium MTT oleh adanya dehidrogenase pada mitokondria yang aktif, menghasilkan produk formazan biru keunguan yang tidak larut. Mekanismenya adalah garam tetrazolium berwarna kuning tersebut akan direduksi di dalam sel yang mempunyai aktivitas metabolik. Mitokondria dari sel hidup yang berperan penting dalam hal ini adalah yang menghasilkan dehidrogenase. Bila dehidrogenase 
tidak aktif karena efek sitotoksik, maka formazan tidak akan terbentuk. ${ }^{14}$ Produksi formazan dapat dihitung dengan melarutkannya dan mengukur densitas optik dari larutan yang dihasilkan, ${ }^{15}$ seperti yang terlihat pada Tabel 1 .

Karbamid peroksida dan hidrogen peroksida telah diterima oleh Food and Drug Administration (FDA) sebagai bahan antiseptik. Antiseptik yang mengandung 10-15\% karbamid peroksida dan 1,5$3 \%$ hidrogen peroksida diklasifikasikan sebagai bahan yang aman dan efektif. Aplikasi karbamid dan hidrogen peroksida untuk pencuci luka di dalam rongga mulut selama 7 hari dan antiseptik selama 2 hari dikatagorikan aman. ${ }^{16}$ Kandungan aktif karbamid dan hidrogen peroksida juga dipakai dalam bahan pemutih gigi. Konsentrasi karbamid maupun hidrogen peroksida dalam bahan pemutih gigi untuk pemakaian di rumah, sama dengan konsentrasi karbamid atau hidrogen peroksida pada produk kesehatan mulut yang telah diterima FDA.

Produk antiseptik mulut sudah lama dipakai dengan aman, sedang keamanan bahan pemutih gigi dipertanyakan karena penggunaannya berbeda. Secara substansi perbedaannya adalah cara aplikasi antara bahan pemutih gigi untuk pemakaian di rumah dan produk kesehatan mulut. Proses pemutihan gigi berkisar satu jam sampai sepanjang malam, ${ }^{17}$ jadi waktu kontak bahan pemutih gigi dengan jaringan mulut lebih lama dari pada bahan antiseptik. Sebagai tambahan, bahan pemutih gigi biasanya merupakan campuran dari beberapa bahan, sehingga kemungkinan ada interaksi dengan bahan lain yang disebabkan sifat aktif peroksida.

Penelitian sitotoksisitas pemutih gigi berdasar konsentrasi bahan dilakukan untuk mengetahui persentase sel hidup beberapa bahan pemutih gigi dengan konsentrasi berbeda. Karbamid peroksida digunakan mewakili bahan pemutih gigi untuk pemakaian di rumah, sedangkan hidrogen peroksida $38 \%$ mewakili pemakaian bahan pemutih gigi di klinik. Karbamid peroksida $10 \%$ setara dengan 3,6\% hidrogen peroksida, ${ }^{2}$ karbamid peroksida $15 \%$ setara dengan $5,3 \%$ hidrogen peroksida, ${ }^{2}$ dan karbamid peroksida $20 \%$ setara dengan $7,5 \%$ hidrogen peroksida. ${ }^{18}$

Alasan mengapa hidrogen peroksida diperhitungkan sebagai faktor risiko untuk kesehatan, adalah karena adanya campuran oksidasi dosis tinggi dan mudah terdekomposisi menjadi radikal hidroksil. Radikal hidroksil sebagai radikal bebas dengan elektron tak berpasangan, siap menyerang molekul lain, menghasilkan radikal bebas dan seterusnya. Kerusakan yang dihasilkan mengacu pada stres oksidatif menyebabkan disfungsi molekuler dan seluler. Kerusakan pada makromolekul esensial oleh oxygen-based reactants menjadi penyebab beberapa penyakit dan juga berpengaruh pada proses menua. ${ }^{19}$

Jumlah sel hidup dalam penelitian ini yang terdeteksi dengan spektrofotometer atau ELISA reader adalah hasil produk MTT. Semakin berwarna ungu, nilai absorben makin tinggi dan makin banyak sel yang hidup. Persentase sel hidup pada kelompok I, II, III, IV adalah sebesar 86,73 $\%, 81,22 \%, 81,82 \%$ dan $64,08 \%$. Jumlah persentase sel hidup di atas $50 \%$ pada semua kelompok, sehingga dapat dikatakan tidak toksik bila dipakai parameter $C D_{50}{ }^{20}$

Pada kelompok I, II, III yang menggunakan karbamid peroksida $10-20 \%$ jumlah persentase sel hidup cukup tinggi (di atas 80\%) dan tidak ada perbedaan bermakna diantara kelompok. FDA menyatakan karbamid peroksida $10-15 \%$ aman. Tidak ada penurunan jumlah sel hidup pada karbamid peroksida 20\% dibandingkan 15\% dalam penelitian ini, sehingga dapat dikatakan konsentrasi karbamid peroksida 10-20\% aman. 
Banyaknya jumlah sel hidup pada bahan pemutih gigi konsentrasi 10-20\%, karena kandungan hidrogen peroksida masih relatif rendah, yaitu 3,6$7,5 \%$. Kelompok IV yang menggunakan hidrogen peroksida konsentrasi paling tinggi yaitu 38\%, didapatkan persentase sel hidup yang paling rendah yaitu $64,08 \%$ mendekati $C D_{50}$, sehingga dapat dikatakan konsentrasi hidrogen peroksida berpengaruh terhadap persentase sel hidup, sesuai pendapat $\mathrm{Li}^{16}$ dan Hanks et al. ${ }^{21}$ Hidrogen peroksida $1 \%$ sebanyak $1 \mathrm{ml}$ melepaskan $3,3 \mathrm{ml}$ oksigen, $10 \mathrm{ml}$ hidrogen peroksida $30 \%$ dapat menghasilkan 1 liter oksigen. ${ }^{16}$ Oksigen yang lebih banyak pada kelompok IV menyebabkan reaksi oksidasi dan kerusakan dalam sel oleh radikal bebas lebih besar. $\mathrm{Li}^{16}$ berpendapat reaksi oksidasi dan kerusakan dalam sel adalah mekanisme utama yang mungkin menyebabkan toksisitas bahan yang mengandung peroksida.

\section{SIMPULAN}

Dari penelitian ini dapat disimpulkan bahwa bahan pemutih gigi karbamid peroksida 10\%, $15 \%, 20 \%$ dan hidrogen peroksida $38 \%$ tidak sitotoksik terhadap sel $B H K-21$ menggunakan esei $M T T$ bila menggunakan parameter $C D_{50}$.

\section{SARAN}

Uji lanjutan disarankan untuk mengetahui biokompatibilitas secara keseluruhan. Dokter gigi disarankan untuk mengikuti aturan pabrik dengan seksama saat aplikasi bahan pemutih gigi, dan aplikasi harus dilakukan dengan hati-hati.

\section{DAFTAR PUSTAKA}

1. American Dental Association (ADA). ADA statement on the safety and effectiveness of tooth whitening products. Updated February 2005. Available from http://www.ada.org/ prof/resources/positions/ statements/whiten2. asp. Accessed 17 June 2005.
2. Scientific Committee on Consumer Products (SCCP). Opinion on hydrogen peroxide in tooth whitening products. European commission. Health \& consumer protection directorate-general. Adopted by the SCCP during the $3^{\text {rd }}$ Plenary Meeting of 15 March 2005. p. 29, 35.

3. O'Brien WJ. Dental materials and their selection. $3^{\text {rd }}$ Ed. Chicago: Quintessence Publ Co.; 2002. p.162-3.

4. Hatrick CD, Eakle WS, Bird WF. Dental materials: Clinical applications for dental assistants and dental hygienists. Philadelphia: Saunders; 2003. p. 101-6.

5. Matis BA. The question-at-home or in-office bleaching: evidence based concepts to empower dental professionals 2004. Available from http://www.bmatis@iupui.edu. Accessed 27 August 2004.

6. Fazwishni S, Hadijono BS. Uji sitotoksisitas dengan esei MTT. Jurnal Kedokteran Gigi Universitas Indonesia 2000; 7: 28-32.

7. Li Y, Zhang W, Ponraj E. Evaluation of cytotoxicity of britesmile light-activated whitening gel using MTT tetrazolium assay 2000. Available from http://britesmile.lv/docs/ white_gel_2_cytotoxity.pdf. Accessed 6 Oct 2006.

8. Lazo Lab. MTT Assay 2006. Available from http://www.pitt.edu/ lazo/MTT.html. Accessed 10 Feb 2006

9. Park JB. Chapter 1 MTT Assay. Available from http://www.pl.barc. usda.gov/ chapters/ chapter1.cfm. Accessed 27 September 2006.

10. Titien HA. 2002. Pengaruh tegangan listrik dan lama penyinaran pada semen ionomeri gelas modifikasi resin terhadap kekerasan permukaan dan sitotoksis [thesis]. Surabaya:Pascasarjana Universitas Airlangga; 2002.

11. Anusavice KJ. Phillips' Science of Dental Materials. $11^{\text {th }}$ ed. Philadelphia. WB Saunders Co.; 2003. p. 9-17.

12. Freshney RI. Culture of animal cells. A manual of basic technique, $2^{\text {nd }}$ ed, New York. AlanR Liss Inc.; 1987. p. 9, 71, 128, 239.

13. Rubianto M. 1998. Biokompatibilitas bahan allograft (human bone powder) dibandingkan dengan bahan alloplast (hydroxylapatite). 
Kumpulan naskah Temu Ilmiah Nasional I (TIMNAS I) FKG UNAIR; 1998. h. 507-9.

14. Kasugai S, Hasegawa N, Ogura H. Application of the MTT colorimetric assay to measure cytotxic effect of phenolic compound on established rat pulp cells. J Dent Res 1991; 70: 127-30.

15. Craig RG, Powers JM. Restorative dental materials. $6^{\text {th }}$ Ed. London: Mosby Co.; 2002. p. 135-40.

16. Li Y. Biological properties of peroxidecontaining tooth whiteners. Food Chem Toxicol 1996; 34: 887-904.

17. Haywood VB, Heymann HO. Nightguard vital bleaching. Quintessence Int 1989; 20: 173-6.

18. Anonymous. Opalescence PF teeth whitening system 10\%, 15\%, 20\%, 35\%. Copyright
2008-2010.Available from http://www. whiteteethsolution/opalesence-white-teeth.

html. Accessed 10 January 2006.

19. Tietz, Vieregge, Vober, Wehrman, Welter, Wood, dkk. Esthetic options: tooth bleaching. 2005. Available from http://www1.umn. edu/dental/courses/dent_6806fall02/paper9/pa per9.html.Accessed 14 August 2005.

20. Telli C, Serper A, Dogan AL, Guc D. Evaluation of the cytotoxicity of calcium phosphate root canal sealers by MTT assay. $\mathbf{J}$ Endodon 1999; 25: 811-3.

21. Hanks CT, Fat JC, Wataha JC, Corcoran JF. Cytotoxicity and dentin permeability of carbamide peroxide and hydrogen peroxide vital bleaching materials, in vitro. J Dent Res 1993; 72: 931-8. 